\title{
A Case Report of Gangrenous Balanitis in Progressive Reaction in Leprosy
}

\author{
DR D. S. CHAUDHURY \\ Senior Medical Officer in Charge \\ DR ( mRs) M. CHAUDHURY \\ Medical Officer \\ Ghana Leprosy Service - P.O. Box 26, Elmina
}

I N T R O DUCT ION

Erythema nodosum leprosum is the most common reactional manifestation of lepromatous leprosy. It occurs as crops of discrete nodules, more rarely as raised patches varying in size from a few $\mathrm{mm}$. to a few $\mathrm{cm}$. in diameter. 'The nodules are usually found on the face and extremities and less often on the trunk. They are painful and tender. The individual nodules last from 3 to 4 days to a week or longer. In the subacute or chronic form, the condition con-

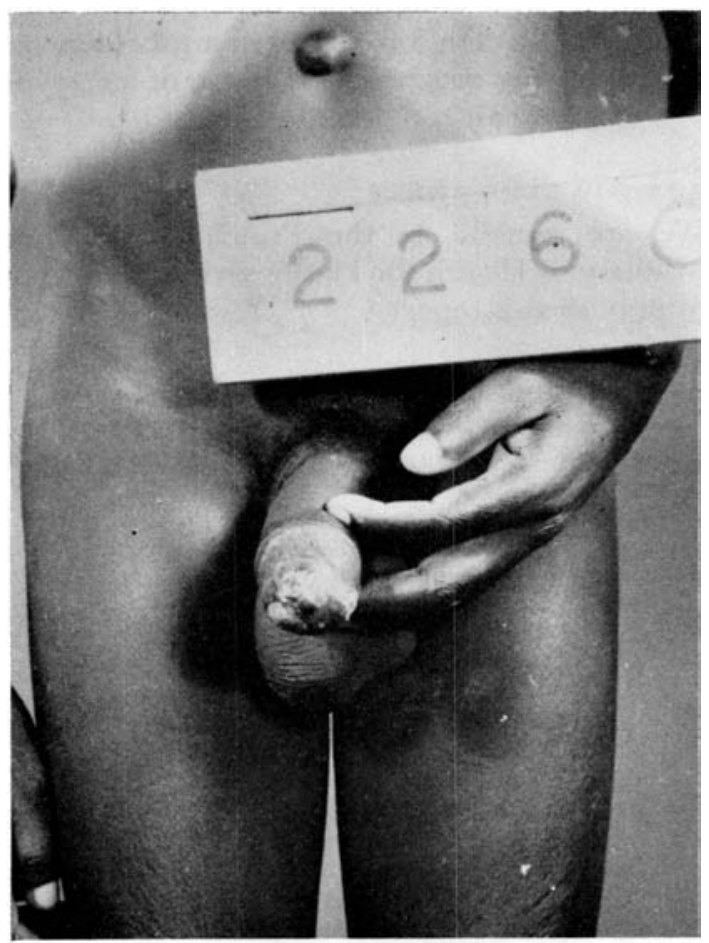

Fig. I. Patient in the ambulant stage. Ulcer on the glands partly healed and scarred. tinues unabated and constitutes a serious reactional condition which Cochrane (I964) describes as 'Progressive Reaction'. The subcutaneous nodules in this type of reaction have a tendency to break down and ulcerate resulting in great distress to the patient. A description of a case of such progressive lepra reaction in a young African where ulcerative breakdown resulted in gangrenous balanitis is given in this paper.

\section{History}

A lepromatous Ghanaian boy of I 5 years, admitted to Ankaful Leprosarium, developed progressive lepra reaction. On admission the patient was graded as infiltrative lepromatous leprosy. His general health was poor and he had oedema in both feet. Prior to his admission to Ankaful Leprosarium, he had treatment for one year at Ho near the Eastern Border of Ghana. Later he was admitted to Ho leprosarium for treatment of frequent subacute reactions. He was referred to Ankaful from Ho. On admission to Ankaful, the following laboratory findings were obtained:

Skin smear - B.I. $=2+($ Ridley $)$

$$
\begin{aligned}
& 50 \% \text { Fragmented } \\
& 50 \% \text { Granular }
\end{aligned}
$$

Haemoglobin $68 \%-9.9$ g. $\%$ (Eel)

Sickling - Negative.

Blood film for malaria and filaria - Negative.

Blood Group - A

Skin snip for Onchocerca Volvulus -

Examination of urine for Schistosoma

$$
\text { Negative. }
$$

haematobium - Negative.

Urine examination for Albumen and Sugar

- Negative.

Examination of stool for hookworm and roundworm - Negative. 


\section{Histopathological Report}

'Epidermis shows flattening of rete pegs. Subepidermal zone partly invaded with lymphocytes. Infiltration mostly perivascular and around skin structures. No follicle formation noticed and few macrophages seen. Nerves invaded but mostly perineuritis. Picture suggests lepromatous leprosy with borderline features'.

\section{Case History}

The patient admitted for treatment in November I 963 has had very frequent erythema nodosum leprosum. He was put on parenteral DDS. I $25 \mathrm{mgm}$. weekly and thiosemicarbazone 75 mgm. daily. In periodic reviews it was observed that B.I. remained fairly constant. He developed severe ENL in September I 964 and after 3 days, there was increase in the nodules with breakdown of a nodule on the glans penis forming a big ulcer. The edges of the ulcer were elevated and indurated. The ulcer covered nearly half the entire glans and extended mostly on the dorsal surface. The granulating base was covered with a thick purulent exudate and dirty necrotic detritus.

There was oedema in the rest of the glans. The patient was acutely ill and also developed several superficial ulcers on the soles of feet. There was no ulceration on the skin of the penis or scrotum.

\section{Treatment}

The management of the patient was by giving intramuscular injections of ACTH, and Fantorin (trivalent antimony), intravenous Terramycin in Dextravan drips, iron and multivitamin by mouth, liver extract and Largactil (chloropromazine) parenterally. The ulcer was dressed with nonad tulle. The recovery was complete although slow.
The ulcerated part of the glans healed with a scar. There was no difficulty in micturition. His general health improved and reactions settled down.

\section{IS C US S I O N}

Gangrenous balanitis as a complication of progressive lepra reaction is not reported in the literature so far. Cochrane mentions orchitis, lymphadenitis, iritis, progressive cachexia and rarely amyloidosis as accompaniments or terminal complications in progressive lepra reaction. Molesworth (1965) confirms occurrences of similar ulcerative breakdowns and sloughing of indurated areas as frequent in Malayan patients. Andrews ( I 954) states that gangrenous balanitis is encountered mostly in young Africans suggesting a racial proclivity. He adds that the condition is extremely painful and sometimes fatal. The common conditions, he mentions, as causing this, are syphilis, chancroid and granuloma inguinale which were excluded in this case.

\section{S U M M A R Y}

A patient with gangrenous balanitis as a complication of ulceration arising in a subcutaneous nodule during progressive reaction of leprosy in a young African is reported.

\section{A CKNOWLEDGMENTS}

We are grateful to the Principal Secretary, Ministry of Health for kindly giving permission to publish this report.

\section{REFERENGES}

Cochrane, R. G. 'Leprosy in Theory and Practice'. p. 339, edited by R. G. Cochrane \& T. F. Davey, 2nd edition, Wright, Bristol.

molesworth, B. D. Personal Communication.

ANDREws, G. C. 'Diseases of the skin', $4^{\text {th }}$ edition. p. 257, W. B. Saunders Co., Philadelphia \& London. 